\title{
The Impact Work-Life Balance toward Job Satisfaction and Employee Retention: Study of Millennial Employees in Bandung City, Indonesia
}

\author{
${ }^{1}$ Hana Silaban, ${ }^{2}$ Meily Margaretha \\ 1,2Management Department, Universitas Kristen Maranatha, Bandung, Indonesia
}

\begin{abstract}
Millennial generation employees are employees who value flexibility in their work. Therefore, work-life balance is one of the factors that can affect the attitude of millennial employees in the company. Job satisfaction is an employee's perspective on his work to see how far the company has met employee expectations. A work-life balance makes employees feel job satisfaction because they can work well while in the office; therefore they do not need to be burdened with problems outside of work. In addition, good quality of work-life balance will increase employee retention so that the company can avoid problems related to employee retention. This research aimed to explore the effect of work-life balance on job satisfaction and employee retention of the millennial generation employees in the city of Bandung, Indonesia. The sample used in this study was 196 employees from various fields of work. Analysis of data used simple linear regression, by testing the quality of the data through validity and reliability test. Study results found that there was an effect of work-life balance on job satisfaction as much as $8.3 \%$, and there was an effect of work-life balance on employee retention of $4.4 \%$. One of the managerial implications of the research results that can be implemented is organization should provide a good work environment and facilities to increase the motivation of the employees.
\end{abstract}

Keywords: Work life-balance, job satisfaction, employee retention, the millennial generation.

\section{Introduction}

In the current era of globalisation, competition between companies is increasing along with the pace of global economic growth. Companies demand that the human resources involved in it must be able to compete, survive and win the competition (Ganapathi, 2016). To achieve the targets that have been given, in general, currently many companies have been implemented work life balance. According to Frame and Hartog in Moedy (2013), work-life balance (WLB) means that employees are free to use their working hours flexibly and balance their work with other commitments. By implementing work-life balance programs in the company, employees will not spend their time doing their works only. However, they can still have a life outside the works, for example, their families, and their social works, therefore it creates a balance that will make employees happier and more satisfied to do their work life.

Yuswohady (2016) explained millennial generation is the generation born in the early 1980s to 2000s. This generation is often referred to as Gen-Y, Net Generation, Generation WE, Boomerang 
Generation, Peter Pan Generation, etc. It is called millennial generation because this kind of generation lives at the turn of the millennium. In 2016, more than $40 \%$ of the total population in Indonesia was a millennial generation and will reach its peak in 2030 with a millennial generation workforce of $70 \%$ (Amalia \& Hadi, 2019). The ideal job for millennials is a job that matches their personality, and when millennials can enjoy their work, this will provide a sense of satisfaction in the work environment and outside of work (Gichuhi \& Mbithuka, 2018). According to Rahmawati et al. (2019), millennials at work do not always prioritise work in their lives but value flexible working hours and a supportive work environment.

Millennial generation employees also expect the company to provide remuneration that is proportional to the workload, professional development and provide a supportive work environment (Amalia \& Hadi, 2019). Another factor that can affect the work-life balance itself is job satisfaction (JS). Employees who do not get job satisfaction will never achieve psychological satisfaction and eventually show negative attitudes or behaviour in the workplace, which in turn can lead to frustration. Meanwhile, employees with job satisfaction will work well, enthusiastically, active and perform better than unsatisfied employees (Khoerunnisa et al., 2019). Some factors that influence job satisfaction, according to Sutrisno (2017), are opportunities for advancement, job security, salary, company and management, supervision, working conditions, social aspects in communication work, facilities. According to Hasibuan (2016), JS is an emotional attitude that is pleasant and loves his job. This attitude is reflected by work morale, discipline, and work performance. Mangkunegara (2017) mentioned two factors affect JS, namely those of employees and their work factors. Employee factors consist of intelligence, special skills, age, gender, physical condition, education, work experience, years of service, personality, emotions, ways of thinking, perceptions, and work attitudes, and for work factors such as type of work, organisational structure, rank, position, quality of supervision, financial security, the opportunity for promotion, social interaction, and work relations. Creating and maintaining employee job satisfaction is important that give an impact on the survival of the company, because satisfied employees give a positive influence on the company, such as increasing efficiency and productivity (Kanwar et al., 2009). When employees have a positive work-life balance, employees will feel satisfaction working for the company and increase their productivity which makes the company try to retain employees because they have shown good performance and provide benefits for the company and it is called employee retention (ER).

Employee retention is one of the important problems facing employers due to the scarcity of skilled labour and employee turnover. ER is considered a crucial challenge for the organisation. According to Johnson et al. (2000), retention is the ability to be attached to employees that the company wants, longer than other companies, therefore it can be said that retention is a long-term relationship or commitment between employees and the company. Employee retention is an important tool for better performance. Organisations today are competing to retain employees for a longer period. These organisations focus on attracting the best people, selecting them, and then retaining talented employees. To retain employees, employers should use practices that benefit both employers and employees and lead them to high standards of performance. To create a sense of association between organizational values and employees, it is very important to recruit employees driven by policies and perspectives. If supervisors provide support to their employees, employees will feel more connected and related to the organisation and in return, they can support the organisation through retention.

\section{Literature Review}


Singh and Khanna (2011) in Pandiangan (2018) state that work-life balance is a broad concept that involves setting the right priorities between "work" (career and ambition) on the one hand and "life" (happiness, leisure, family and development). According to Lestari dan Margaretha (2021), WLB is a situation that gives employees opportunities to balance their career work life and their personal life, and this situation will not lead to job stress and fatigue in doing their works. WLB is one factor that influences on employee commitment, job satisfaction and organisation productivity.

Siagian and Sondang (2002) argued that job satisfaction is a way for the employee to see the work they have done, whether it is good or bad. Meanwhile, according to Kuswadi (2005), job satisfaction is the fulfilment of employee needs by their expectations. It can be concluded that job satisfaction (JS) is a personal thing; everyone has a different level, and leaders need paying attention to see the extent to which the company meets the expectations of its employees.

Employee retention is one of the movements carried out by an organisation to create an environment that involves employees for the long term (Chaminade, 2006). Employee retention is the main goal and main concern for most organizations. Retention of talented employees is an advantage for the organisation because employees with high knowledge and expertise or skills are very important for the company's ability to be economically competitive (Kyndt et al., 2009). It concluded that employee retention is a challenge for organisations to keep their employees and the main goal and concern of the organisation. Many factors affect employee retention such as organisational factors, career opportunities, rewards, and employee relations.

\subsection{Work-life Balance and Job Satisfaction}

Fisher et al. (2003) mentioned that WLB is something that is done to make a balance division of time between work and outside of work. Outside of work, there are usually individual behaviours that can make personal conflict and energy for ourselves. When a worker carries out both responsibilities between work and his role in the family, there will create job satisfaction because by working at the company, an employee will not feel burdened by problems outside of work. According to Robbins and Coulter (2012) WLB program includes resources for caring for parents and children, healthy, and welfare of employees. Therefore, many companies have offered programs to meet the needs of employees in creating a balance between life and work; these programs include family-friendly benefits, flex time, job sharing, telecommunicating and others. This statement is supported by research conducted by Qodrizana (2018) that showed work-life balance affected job satisfaction. The important point is to balance the level of someone's satisfaction at work and outside work. If someone can give time to the needs of work and outside work well, it will create job satisfaction. Based on this explanation, the researcher proposes the first hypothesis in this study:

$\mathrm{H} 1$ : There is an influence between work-life balance on job satisfaction.

\subsection{Work-life Balance and Employee Retention}

Employee retention is an important challenge for organisations and the times of knowledge workers (Ferreira in Too \& Kwasira, 2017). Currently, the labour market belongs to employees because talented candidates in the global job skills market have luxurious options (Too \& Kwasira, 2017). Employees, new or old, realise that they are more flexible in choosing an organisation (Clarke, 2001). The dynamic environment of today's business has brought many organisational challenges, one of which is retaining skilled workers. However, to retain employees, the company must implement the WLB program. This statement is supported by research conducted by Too and Kwasira (2017) that showed rewards and compensations have the second-strongest influence on organisational performance after the practice of work-life balance, and the results of their study has shown that WLB has a positive relationship with employee retention. Garg (2016) also stated that work-life balance has a positive effect on employee retention. The conclusion of Grag's research stated that 
companies need to increase the use of work-life balance options such as flexible time, division of labour, and taking breaks from work so that employees can feel that the organisation facilitates their coordination in family and professional work life. Based on this explanation, the researcher proposed the second hypothesis:

$\mathrm{H} 2$ : There is an influence between work-life balance on employee retention.

The research model used in this study is depicted in Figure 1.

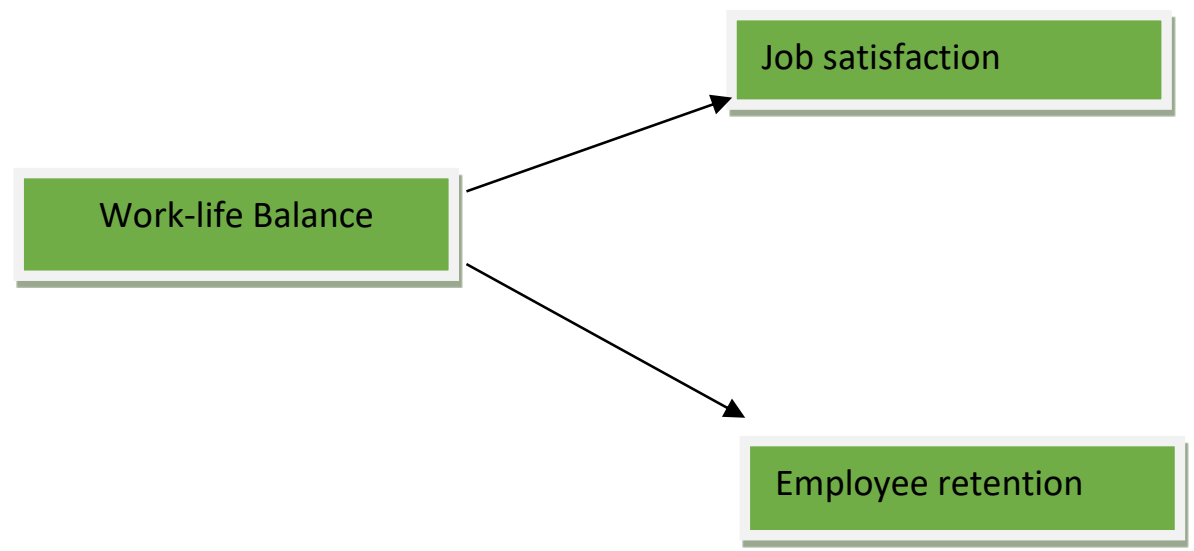

Figure 1: Research Model

\section{Research Methodology}

Quantitative research using the survey method was adopted, and online questionnaires were distributed to a total of 196 millennial generation employees in the city of Bandung as the respondent in this study. To be understood by the respondents, the questionnaire was translated into Bahasa Indonesia. The research questionnaire consisted of 42 questions divided by three instruments, namely work-life balance, job satisfaction and employee retention.

Work-life balance is measured using an instrument developed by Hayman (2005) and consists of 10 questions; for example I often ignore my personal needs because of the demands of my job. Job satisfaction consists of 27 questions, example of the statement is I am satisfied with the salary that I receive from my work. Employee retention consists of 5 questions, for example I want to stay with my company because there is career advancement for me.

Furthermore, data collection was analysed using validity and reliability tests and regression analysis used to test the two hypotheses to show the relationship and influence between work-life balance, job satisfaction and employee retention.

\section{Data Analysis and Interpretation}


Based on the table 1 respondent characteristics, most of respondents are female, as many as 133 respondents (67.9\%). The age of most respondents categorised in the age range of 21-25 years is as many as 144 respondents (73.5\%). Marital status concluded that respondents who have unmarried status are 160 respondents (81.6\%) and respondents with married status are 36 (18.4\%) respondents. Based on educational background, most respondents have bachelor's degrees as many as 146 (74.5\%) respondents. Confirmatory factor analysis was also used in this research by the underlying theories. According to Hair et al. (2010), a construct is valid if the factor loading is above 0.40 . Confirmatory factor analysis of the three constructs in this study showed the loading factor of question items between 0.444 and 0.703 . This reliability value for work-life balance was $0.808,0.903$ for job satisfaction, and employee retention was 0.841 . Table 2 provides the factor loading and Cronbach alpha (CA) for each variable used in this study, and variables said reliable if it gives the CA value> 0.7 in the test results (Hair et al., 2010).

Table 1: Respondent Characteristics

\begin{tabular}{|l|l|l|l|}
\hline Variable & Category & Frequency & \% \\
\hline Gender & Male & 63 & $32.1 \%$ \\
& Female & 133 & $67.9 \%$ \\
\hline Age & $21-25$ years old & 144 & $73.5 \%$ \\
& $26-30$ years old & 30 & $15.3 \%$ \\
& $31-35$ years old & 14 & $7.1 \%$ \\
& $36-41$ years old & 8 & $4.1 \%$ \\
\hline Marital Status & Married & 36 & $18.4 \%$ \\
& Single & 160 & $81.6 \%$ \\
\hline Educational Background & High School & 21 & $10.7 \%$ \\
& Diploma & 24 & $12.2 \%$ \\
& Bachelor & 146 & $74.5 \%$ \\
& Master & 5 & $2.6 \%$ \\
\hline Length of Work & L1 years & 51 & $26 \%$ \\
& $1-2$ years & 113 & $57.7 \%$ \\
& $3-4$ years & 25 & $12.8 \%$ \\
& $5-6$ years & 2 & $2.6 \%$ \\
& $>6$ years & 32 & $1.0 \%$ \\
\hline Field of Work & IT & 9 & $16.3 \%$ \\
& Designer & 6 & $4.6 \%$ \\
& Accounting & 20 & $3.1 \%$ \\
& Finance & 7 & $10.2 \%$ \\
& Logistic & 18 & $3.6 \%$ \\
& Marketing & 7 & $9.2 \%$ \\
& Health & 10 & $3.6 \%$ \\
& Education & 7 & $5.1 \%$ \\
& Hotel & 2 & $3.6 \%$ \\
& HRD & 4 & $1.0 \%$ \\
& Industry & $2.0 \%$ \\
& Others & $37.8 \%$ \\
\hline
\end{tabular}

Source: Data Processed (2021)

Table 2: Validity and Reliability Tests Result 
Hana Silaban, Meily Margaretha

The Impact of Work-Life Balance toward Job Satisfaction and Employee Retention: Study of Millennial Employees in Bandung City, Bandung

\begin{tabular}{|c|c|c|c|}
\hline & \multicolumn{3}{|c|}{ Component } \\
\hline & 1 & 2 & 3 \\
\hline WLB1 & & .553 & \\
\hline WLB2 & & .622 & \\
\hline WLB3 & & .573 & \\
\hline WLB5 & & .612 & \\
\hline WLB6 & & .578 & \\
\hline WLB7 & & .622 & \\
\hline WLB8 & & .651 & \\
\hline WLB9 & & .611 & \\
\hline WLB10 & & .688 & \\
\hline JS8 & .496 & & \\
\hline JS9 & .582 & & \\
\hline JS10 & .528 & & \\
\hline JS11 & .553 & & \\
\hline JS12 & .510 & & \\
\hline $\mathrm{JS} 13$ & .592 & & \\
\hline JS14 & .600 & & \\
\hline JS15 & .568 & & \\
\hline JS16 & .606 & & \\
\hline JS17 & .659 & & \\
\hline JS18 & .684 & & \\
\hline JS19 & .649 & & \\
\hline JS20 & .640 & & \\
\hline JS21 & .662 & & \\
\hline JS22 & .653 & & \\
\hline JS23 & .464 & & \\
\hline JS24 & .658 & & \\
\hline JS25 & .444 & & \\
\hline ER1 & & & .627 \\
\hline ER2 & & & .729 \\
\hline ER3 & & & .735 \\
\hline ER4 & & & .703 \\
\hline ER5 & & & .581 \\
\hline $\begin{array}{c}\text { Cronbach Alpha } \\
\mathrm{N}\end{array}$ & $\begin{array}{l}.903 \\
196\end{array}$ & .808 & .841 \\
\hline
\end{tabular}

Source: Data Processed (2021)

The outcomes of this study have indicated the relationship between WLB toward JS with millennial generation employees in Bandung, Indonesia as the respondents, the value of R-Square of 0.083 and the significance value $=0.000$ have shown that work-life balance influences job satisfaction. This result is having the same result as the research of Haar et al. (2014) which stated that there is a positive relationship between work-life balance and job satisfaction. This study also proves the opinion of Greenhaus et al. (2003) in Haar et al. (2014), who believe that someone with a worklife balance is more satisfied with work because they have participated in an important role.

For the second hypothesis, the result showed the effect of work-life balance on employee retention of millennial generation employees with the value of $\mathrm{R}$ square of 0.044 and a value of significance $=0.003$ which means that there is an effect of life balance work on employee retention. The results of this study are supported by research conducted by Hashim (2016) that mentioned there is a positive relationship between work-life balance and employee retention research. By avoiding worklife balance, it will create negative consequences for employees and directly impact the organisation 
itself. Therefore, it is important to manage the work-life balance of the organisation and retain employees because employees are the backbone of the organisation.

Table 3: Summary of Hypotheses

\begin{tabular}{|l|l|l|l|l|l|}
\hline Variables & R Square & $\begin{array}{l}\text { Adjusted } \\
\text { Square }\end{array}$ & $\boldsymbol{\beta}$ & $\mathbf{t}$ & Sig \\
\hline WLB => JS & .083 & .079 & -.546 & -4.189 & .000 \\
WLB => ER & .044 & .039 & -.146 & -2.993 & .003 \\
\hline
\end{tabular}

Source: Data Processed (2021)

$Y$ generation or millennial generation employees have an awareness of the need for effort and hard work to complete work both in new ways and by using existing systems (Questibriliain, 2019). According to the research of Kultalahti and Viitala (2014), one factor that need to be considered for millennial generation employees is being flexible at work when needed, and they are not ready to sacrifice their personal life, and this result is in line with others research (Haar et al., 2014; Rene \& Wahyuni, 2018; Rondowunu et al., 2018) which showed there was a positive influence between work-life balance toward job satisfaction. The individual with a work-life balance is more satisfied with their work because can participate in an important role (Greenhaus et al., 2003 in Haar et al., 2014). The problem of job satisfaction is important because high satisfaction will create a pleasant work atmosphere and encourage employees to improve their performance.

According to Chaminade (2006), retention is a voluntary movement carried out by an organization to create an environment that involves employees for the long term. Employee retention is the main goal and main concern for most organisations. Employee retention provided is an advantage for the organisation because the knowledge and skills possessed by employees are very important for the company's ability to be economically competitive (Kyndt et al., 2009). The result of this study has indicated the effect of work-life balance on employee retention. The results of this study are supported by other researchers such as Hashim (2016) and Suman Babu and Bhavana Raj (2013). Therefore, it is important to manage organisational life balance and retain employees because employees are important assets of the organisation. The organisation must observe the moods, attitudes, behaviours, and environment of their employees because it is related with the performance of employees. Organisations should also consider other practices that will increase employee retention.

\section{Conclusion and Recomendations}

Work-life balance is not a new concept in human resource research; therefore, this topic will always be examined in many studies. This study has shown evidence that there is an influence between work-life balance on job satisfaction as much as $8.3 \%$ and there is an influence between work life balance on employee retention as much as $4.4 \%$. In addition, this research has important implications for leadership in the company, such as providing a good work environment, supporting facilities to provide morale for employees, practising fair compensation and salary without giving excessive burden to and building good communication between employees and leaders. Companies can relate employees' abilities into jobs that match their interests within the company and give the opportunity to develop through training and development programs designed by the company. Therefore, it can also build good relationships with co-workers. Companies provide employees with the facility to work from home to improve the balance of personal life with the work life of employees. 
Every research has been carried out with the possibility of obstacles and limitations; therefore, the researcher suggests several important things such as for further research, it is expected to deepen and expand the variables in this study and examine other variables that have not been studied such as leadership, work motivation or other work behaviours; next research can choose a particular industry to describe the influence between variables more specifically, and give more time to distribute questionnaires.

\section{References}

- Amalia, R. S., \& Hadi, C. (2019). Pengaruh work design characteristics, career growth, dan psychological capital terhadap work engagement karyawan generasi milenial di PT XYZ/ The effect of work design characteristics, career growth, and psychological capital on work engagement of millennial employee at PT XYZ. Jurnal Psikologi, Vol. 15(1), 10-24. Crossref

- Biason, R. S. (2020) The Effect of job satisfaction on employee retention. International Journal of Economics, Commerce and Management, Vol. 8(3), pp. 405-413.

- Chaminade, B. (2007). A retention checklist: how do you rate? Retrieved from http://www.humanresourcesmagazine.co.au., on April 11, 2020.

- Fisher-McAuley, G., Stanton, J., Jolton, J., \& Gavin, J. (2003). Modelling the relationship between work-life balance and organizational outcomes. Paper presented at the Annual Conference of the Society for Industrial Organizational Psychology, 1-26. Crossref

- Ganapathi, I. M. D., \& Gilang, A. (2016). Pengaruh work-life balance terhadap kepuasan kerja karyawan (studi pada PT. Bio Farma Persero/ The impact of worklife balance towards job satisfaction study on Bio Farma Company. E-jurnal Ecodemica, 4.

- Garg, P, Yajurvedi, N. (2016). Impact of work-life balance practices on employees retention and organizational performance-a study on it industry. Indian Journal of Applied Research, Vol. 6(8), pp. 105-8.

- Gichuhi, J. K., \& Mbithuka, J. M. (2018). Influence of work engagement on millennial employees' retention among insurance industry in Kenya. International Journal of Innovative Research and Development, Vol. 7(2), pp. 145-153.

- Haar, J. M., Russo, M., Sune, A., \& Ollier-Malaterre, A. (2014). Outcomes of worklife balance on job satisfaction, life satisfaction and mental health: a study across seven cultures. Journal of Vocational Behaviour, Vol. 85, pp. 361-373. Crossref

- Hair, J. F., Anderson, R. E., Babin, B. J., \& Black, W. C. (2010). Multivariate data analysis a global perspective (7th ed). United States: Pearson Education.

- Hashim, A., Asman N. S., Ghani A. M., \& Sabri. M. F. M. (2016). The relationship between work life balance and employee retention. Proceeding of the 3rd International Conference on Management \& Muamalah 2016 (3rd ICoMM), 316322.

- Hasibuan, M. S. P. (2016). Manajemen sumber daya manusia/ Human resource management. Jakarta: Bumi Aksara.

- Hayman, J. (2005). Psychometric assessment of an instrument designed to measure work life balance. Research and Practice in Human Resource Management, Vol. 13(1), pp. 85-91.

- Johnson, J, Griffeth, R.W., \& Griffin, M. (2000). Factor discrimination functional and dysfunctional sales force turnover. Journal of Business \& Industrial Marketing, Vol. 15(6), pp. 399-415. Crossref

- Kanwar, Y. P. S., Singh, A. K., \& Dwani, A. D. (2009) Work-life balance and burnout as predictors of job satisfaction in the IT-ITES industry. The Journal of Business Perspective, 13(2), pp. 1-12. Crossref 
- Khoerunnisa, Y., \& Rahayuningsih, N. (2019). Pengaruh motivasi dan kepuasan kerja terhadap kinerja/ The influence of motivation and job satisfaction towards performance. Jurnal Investasi, Vol. 5(2), pp. 42-61. Crossref

- Kuswadi. (2005). Cara mengukur kepuasan karyawan/ How to measure employee satisfaction. Jakarta: Alex Media Komputindo.

- Kyndt, E., Dochy, F., Michielsen, M. \& Moeyaert, B. (2009). Employee retention: organizational and personal perspectives. Vocations and Learning, Vol. 2(3), pp. 195-215. Crossref

- Lestari, D., \& Margaretha. M. (2021). Work life balance, job engagement and turnover intention: Experience from $\mathrm{Y}$ generation employees. Management Science Letters, 11(1), 165-170. Crossref

- Mangkunegara, A. A. A. P. (2019). Manajemen sumber daya manusia/Human Resource Management of Company. Bandung: Remaja Rosda karya Offside.

- Moedy, D. M. R. (2013). Analisis work-life balance, keinginan untuk meninggalkan organisasi, kepenatan (burnout) dan kepuasan kerja pada dosen universitas atma jaya yogyakarta/Analysis of work-life balance, desire to leave the organization, burnout and job satisfaction at Atma Jaya University lecturers, Yogyakarta. EJournal Atma Jaya University Yogyakarta. Retrieved from dari http://ejournal.uajy.ac.id/3898/

- Pandiangan, H. (2018). Flexible working arrangement and its effect on work life balance on online transportation service drivers in Yogyakarta City. Master's thesis in Management Faculty of Economics, Sanata Dharma University, Yogyakarta.

- Robbins, S. P. \& Coulter, M. (2012). Manajemen/Management. Jakarta: Erlangga.

- Siagian, S. (2002). Manajemen sumber daya manusia/Human resource management. Jakarta: Bumi Aksara.

- Sutrisno, E. (2017). Manajemen sumber daya manusia/Human resource management. Jakarta: Kencana.

- Rahmawati, Z., \& Gunawan, J. (2019). The relationship between job-related factors on work life balance and job satisfaction in millennial generation workers. Science and Art Journal, Vol. 8(2), pp. 18-23.

- Too, R., \& Kwasira, D. J. (2017). Evaluation of employee retention practices to generation $\mathrm{Y}$ at cooperative bank in the country of Nairobi, Kenya. European Journal of Business and Management, Vol. 9(11), 43-53.

- Qodrizana, D. L., \& Al Musadieq, M. (2018). Pengaruh work-life balance terhadap kepuasan kerja (Studi pada karyawan perempuan yayasan insan permata tunggulwulung kota malang)/ The effect of work-life balance on job satisfaction (study on female employees of the Insan Permata Tunggulwulung Foundation, Malang City). Jurnal Administrasi Bisnis, Vol. 60(1), pp. 9-17. 